\title{
УНІФІКАЦІЯ ТА ГАРМОНІЗАЦІЯ ІНФОРМАЦІЇ В АРТРОЛОГІЇ ДЛЯ СТВОРЕННЯ СИСТЕМИ ПРОГНОЗУВАННЯ РЕЗУЛЬТАТІВ ОПЕРАТИВНОГО ВТРУЧАННЯ
}

\author{
Національний університет фрізичного виховання і спорту України
}

\begin{abstract}
У статті розглядаються можливості створення інформаційної бази для автоматизованої діагностики та прогнозування результатів оперативного втручання при гонартрозі. Єдиний інформаційний документ слугує створенню в тривимірному просторі системи прийняття рішень. На одній площині реєструються первинні ознаки захворювання, на другій - результати попереднього оброблення отриманих відомостей за допомогою прийнятих міжнародних опитувальників. Нарешті, на третьому представляються результати «голосування» висновків для остаточного прийняття рішень.
\end{abstract}

Ключові слова: оцінювання тяжкості хворих із гонартрозом, прогнозування результатів оперативного втручання, інформаційні підходи, уніфікація інформаційного забезпечення, гармонізація термінів у проблемі лікування хворих на гонартроз.

\section{УНИФИКАЦИЯ И ГАРМОНИЗАЦИЯ В АРТРОЛОГИИ ДЛЯ СОЗДАНИЯ СИСТЕМЫ ПРОГНОЗИРОВАНИЯ ИСХОДОВ ОПЕРАТИВНОГО ВМЕШАТЕЛЬСТВА}

\author{
М. М. Риган \\ Национальный университет фризического воспитания и спорта Украины
}

\begin{abstract}
В статье рассматриваются возможности создания информационной базы для автоматизированной диагностики и прогнозирования исходов оперативного вмешательства при гонартрозе. Единый информационный документ служит созданию в трехмерном пространстве системы принятия решений. На одной плоскости регистрируются первичные признаки заболевания, на второй - результаты предварительной обработки полученных сведений с помощью принятых международных опросников. Наконец, на третьей представляются результаты «голосования» заключений для окончательного принятия решений.
\end{abstract}

Ключевые слова: оценка тяжести больных с гонартрозом, прогнозирование исходов оперативного вмешательства, информационные подходы, унификация информационного обеспечения, гармонизация терминов в проблеме лечения больных гонартрозом.

\section{UNIFICATION AND HARMONIZATION ARTHROLOGY INFORMATION TO CREATE THE SYSTEM FOR OPERATIVE OUTCOMES PREDICTION}

M. M. Ryhan

\author{
National University of Physical Education and Sport of Ukraine
}

\begin{abstract}
This article discusses the possibility of establishing an information base for automated diagnosis and predicting the outcomes of surgery in gonarthrosis. The unified information document provides the creation of three-dimensional space for decisionmaking system. Recorded on the same plane the primary symptoms of the disease, the second - the results of preprocessing the information obtained using internationally accepted questionnaires. Finally, the third presents the results of "voting" for final conclusions decision.
\end{abstract}

\footnotetext{
Key words: assessment of severity in patients with gonarthrosis, predicting outcomes of surgical intervention, informational approaches, harmonization of information security, harmonization of terms in the problem of the treatment of patients with gonarthrosis.
} 
Вступ. У всьому світі зростає кількість захворювань опорно-рухової системи та в першу чергу - деструктивно-дистрофічних процесів. Ці патології в структурі захворюваності населення займають перше місце. На думку ряду вчених, захворювання кісток i суглобів є головною причиною стійкого болю та погіршення фізичного стану сучасної людини $[1,6]$.

Цілком очевидно, що необхідні нові зусилля щодо системного вивчення процесів, котрі відбуваються в організмі людини та призводять до істотного погіршення її здоров'я. Інформатизація закладів охорони здоров'я, що займаються подібними процесами, по суті, $\epsilon$ першим кроком у створюваній системі глобального вивчення проблеми патології опорно-рухової системи.

Мета роботи - створення єдиного інформаційного документа для вирішення клінічних завдань - діагностики, оцінювання стану пацієнта, прогнозування результатів хірургічного втручання.

Основна частина. Проблема ефективного лікування гонартрозів має не тільки медико-соціальне, але й економічне значення. Незважаючи на пильну увагу до патології серед фахівців і достатньо довгий досвід спостережень, недостатня вивченість етіології та патогенезу дегенеративних хвороб суглобів, пізня діагностика, різноманіття варіантів прояву і перебігу, ускладнення - все це значно утруднює вибір адекватного лікування [I, 2, 5].

Відомо, що гонартроз є наслідком найрізноманітніших патологічних процесів, починаючи від вродженої дисплазії кісткової системи і закінчуючи ушкодженнями анатомічних структур суглоба. Оскільки до теперішнього часу патогенез захворювання до кінця не вивчений, то й вибір способів лікування далеко не очевидний.

Слід розробити систему прогнозування розвитку патологічного процесу, створити стандартні схеми розрахунку прогностичних показників для визначення ефективності запропонованого виду локальної терапії або використання хірургічних методів. При цьому повинні застосовуватися обгрунтовані підходи перспективного прогнозування середніх величин показників артрологічного статусу. Для практичного застосування важливо розробити алгоритми обстеження хворих на остеоартроз і шкали прогностичних показників для оцінювання результатів лікування.

Важливого значення набувають питання оцінювання факторів ризику. Концепція оцінювання ризику практично всіма вченими розглядається в якості головного механізму розроблення та прийняття управлінських рішень в оптимізації тактики ведення хворих.
У рамках концепції управління ризиками особливе місце займають питання клінічного моніторингу. Останній, як система спостереження, аналізу, оцінювання та прогнозу стану здоров'я хворих, а також визначення причинно-наслідкових зв'язків між станом здоров'я населення та впливом факторів середовища перебування людини $\epsilon$, з однієї сторони, засобом управління ризиками (в тому числі, шляхом моніторингу експозицій і ризиків, динамічного спостереження за прямими і непрямими індикаторними показниками), а з іншої, - системою, що надає відомості про реальний вплив факторів ризику.

Слід зауважити, що всебічне оцінювання ризику впливу на здоров'я хворого всіх потенційних факторів хоча й бажане, але реально нездійсненне через великий обсяг досліджень і необхідних матеріальних ресурсів, а також через відсутність адекватних даних про рівні впливу та потенційної небезпеки ризиків. У зв'язку з цим аналіз зазвичай проводиться на основі детального дослідження обмеженого числа пріоритетних (індикативних) показників, що найкраще характеризують реальний ризик для здоров'я пацієнтів.

Отже, методологію оцінювання й управління ризиками можна розглядати в якості одного з основних, системоутворювальних елементів клінічного моніторингу. Важливу роль оцінювання ризику відіграє в процедурах оптимізації та відбору пріоритетних факторів для моніторингу, визначенні показників для контролю експозицій, обгрунтуванні вибору індикативних показників, засобів вимірювання, їх періодичності.

Результати та їх обговорення. Нами створюється система моніторингу й управління факторами ризику хворих на гонартроз. Вона складається 3 двох кластерів: перший базується на класичних дослідженнях в амбулаторних умовах, другий - в рамках спеціалізованих клінічних установ. Однією з особливостей нашої системи є застосування нових факторів ризику, що побудовані на відносних показниках, котрі відображають особливості динаміки показників і часу експозицій факторів ризику. Іншою особливістю $є$ вивчення оперативних індивідуальних коефіцієнтів кореляції між простими та високоінформативними факторами ризику для отримання індикативних показників.

Для дослідження розроблено спеціальну карту обстеження хворого 3 артрологічною патологією (ОХАП). Структурно вона складається зі 141 запитання, симптомів та інших ознак, поділених на блоки, що відображають стан таких систем організму: серцево-судинної, легеневої, травної, сечостатевої, ен- 
докринної, а також психоемоційної сфери. Відповіді на запитання в кожному блоці допомагають лікарю виявити скарги або патологічні процеси вже наявні у пацієнта й акцентувати увагу на наявних факторах ризику виникнення захворювання, пов'язаних із професійними шкідливостями, генетичними аспектами тощо.

Вся первинна інформація об'єднана в 14 блоків, що об'єднують: скарги пацієнта, сімейний анамнез, об'єктивне обстеження, антропометричні показники, соціальні звички, дані лабораторних та інструментальних методів. Особливістю карти є документальне та віртуальне відображення інтегральної оцінки тяжкості стану пацієнта за допомогою спеціальних опитувальників, що визнані й використовуються в усьому світі.

Оскільки загальні висновки кожного з опитувальників можуть не співпадати, організовано процедуру голосування діагностичних і прогностичних моделей.

Отже, реалізовано реєстрацію й оброблення первинної інформації в багатовимірному просторі.

На першій площині реєструвалася базова (первинна) інформація. За допомогою різних прийнятих міжнародною громадськістю опитувальників первинні дані підсумовувалися у вигляді діагностичних і прогностичних висновків, останні утворювали другу площину інформації. Нарешті, на третьому рівні фіксувалися дані, отримані після процедури «голосування» висновків. Відносно кажучи, вони служили основою при прийнятті діагностичних і лікувальних рішень.

Кожен блок має наскрізне кодування, що дозволяє полегшити внесення інформації до комп'ютера. Для забезпечення єдиної інтерпретації кожен показник має уніфіковані градації. Наприклад:
Кількість шлюбів: 18.

Діти від попередніх шлюбів: 19. так - 1; ні - 2

Професійні шкідливості: 20. так - 1; ні - 2

Шкідливі звички: 21. так - 1; ні - 2

Якщо так, то які: 22. куріння - 1; алкоголь - 2; наркотичні речовини - 3

Дії токсичних/тератогенних факторів: 23. так - 1; ні - 2

Фізичні навантаження: 24. підвищені - 1; нормальні - 2; знижені - 3.

В роботі зроблена спроба проаналізувати нові показники, пов'язані з аналізом їх динаміки. Зміна показників відображається в динаміці з періодичністю в 3 місяці протягом 1 року. Одночасно отримана інформація забезпечує моніторинг стану пацієнта (табл. 1).

Таблиця I. Показники змін антропометричних показників

\begin{tabular}{|l|c|c|c|}
\hline \multirow{2}{*}{\multicolumn{1}{|c|}{ Показник }} & \multicolumn{3}{|c|}{ Термін } \\
\cline { 2 - 4 } & $\begin{array}{c}\text { через } \\
\text { 3 міс. }\end{array}$ & $\begin{array}{c}\text { через } \\
6 \text { міс. }\end{array}$ & $\begin{array}{c}\text { чере3 } \\
1 \text { рік }\end{array}$ \\
\hline Індекс маси тіла (ПМТ) & & & \\
\hline Окружність талії (ОТ) & & & \\
\hline Окружність стегон (ОС) & & & \\
\hline ОТ/ОС & & & \\
\hline
\end{tabular}

Реалізовано також складні табличні методи відображення інформації (табл. 2).

Підкреслимо, що більшість показників добре відомі, а особливістю є вторинний аналіз дисперсії характеристик даних математичного аналізу антропометричних показників, що здійснювався таким чином, щоб забезпечити вивчення показників розбіжностей другого порядку.

Таблиця 2. Методи відображення інформації

\begin{tabular}{|l|c|c|c|c|c|c|}
\hline & $\begin{array}{c}\text { Весь } \\
\text { час }\end{array}$ & $\begin{array}{c}\text { Більшу } \\
\text { частин } \\
\text { у часу }\end{array}$ & Часто & Іноді & Рідко & $\begin{array}{c}\text { Жодно } \\
\text { го разу }\end{array}$ \\
\hline А. Ви відчували себе бадьорим(ою)? 44. & 1 & 2 & 3 & 4 & 5 & 6 \\
\hline Б. Ви сильно нервували? 45. & 1 & 2 & 3 & 4 & 5 & 6 \\
\hline $\begin{array}{l}\text { В. Ви відчували себе таким(ою) пригніченим(ою), } \\
\text { що нічого не могло Вас підбадьорити? 46. }\end{array}$ & 1 & 2 & 3 & 4 & 5 & 6 \\
\hline $\begin{array}{l}\text { Г. Ви відчували себе спокійним (ою) і } \\
\text { умиротвореним(ою)? 47. }\end{array}$ & 1 & 2 & 3 & 4 & 5 & 6 \\
\hline
\end{tabular}

Аналогічний підхід запропоновано для реєстрації ЕКГ, біохімічних характеристик тощо.

Наявність у пацієнтів генетичної схильності виявляли за допомогою таких питань:

\begin{tabular}{|l|l|}
\hline 20 & Ваші родичі мали захворювання суглобів? \\
\hline 21 & Ваші родичі перенесли інсульт (параліч)? \\
\hline 22 & $\begin{array}{l}\text { Ваші родичі страждали від підвищення } \\
\text { артеріального тиску? }\end{array}$ \\
\hline
\end{tabular}


Запитання про перенесені пацієнтом захворювання одразу ж допомагало отримати уявлення про стан пацієнта, наявність основної та супутньої патології. Інша методика була запропонована для вивчення факторів ризику виникнення гонартрозу, його ранньої діагностики та профілактики, для чого використовувалася спеціальна анкета.

Одночасно при складанні карти обстеження забезпечували стандартизацію та гармонізацію термінів. Вони проводились у відповідність до методичної рекомендації з гармонізації термінології на національному та міжнародному рівнях [7].

Можливість проведення подібного процесу особливо актуальна, якщо взяти до уваги багатозначність понять у такій предметній області, що швидко розвивається, як артрологія.

Для вирішення питань стандартизації термінів і понять раніше розроблено та введено в дію ряд основних нормативних документів, що регламентують створення систем термінологічних стандартів і тлумачних словників.

\section{Лiтература}

1. Багирова Г. Г. Остеоартроз: эпидемиология, клиника, диагностика, лечение / Г. Г. Багирова, О. Ю. Мейко. - М., 2005. $-224 \mathrm{c}$.

2. Бадокин В. В. Пути оптимизации терапии остеоартроза /

В. В. Бадокин // Русский медицинский журнал. - 2006. -

Т. 14, № 5. - С. 1824-1828.

3. Гейдешман Е. С. Выбор способа хирургического лечения больных с дефектами хряща коленного сустава при гонартрозе : автореф. ... дисс. к.мед.н. - Самара, 2008. $23 \mathrm{c}$.

4. Григорян Б. С. Корригирующие операции в лечении гонартроза : автореф. ... дисс. к.мед.н. - М., 2003. - 26 с.
Базовим поняттям зазначених документів є поняття "гармонізація". При цьому гармонізація власне понять визначається як цілеспрямована діяльність, що дозволяє усунути або знизити до прийнятного рівня відмінності, які стосуються різних поняттєвих систем, котрі описують один і той же об'єкт стандартизації. Гармонізація понять здійснюється не тільки в рамках систем понять, виражених різними мовами, але і в рамках однієї мови.

Під гармонізацією термінів розуміють цілеспрямовану діяльність, у результаті якої одне поняття в різних мовах позначається термінами, що мають одні й ті ж або подібні ознаки, або мають однакову, або таку, що злегка відрізняється, форму. Дане визначення наводиться в документах ICO/ТК 37.

Висновки. I. Запропоновано систему реєстрації інформації для узагальнення досвіду діагностики та лікування гонартрозу.

2. Розроблено багатовимірну систему реєстрації інформації. Використовуються три рівні - первинний, рівень попередніх висновків, інформація для прийняття діагностичних і лікувальних рішень.

5. Long-term follow-up after osteotomy for haemophilic arthropathy of the knee Text. / T. Wallny, A. Saker, P. Hofmann, H. Brackmann // Haemophilia. - 2003. -Vol. 9, № I. - P. 69.

6. Шостак Н. А. Остеоартроз - современные подходы к диагностике и лечению / Н. А. Шостак // Русский медицинский журнал. - 2003. - № 14. - С. 803.

7. Р 50-603-2-93 Рекомендации. Методические рекомендации по гармонизации терминологии на национальном и международном уровне. Госстандарт. - М., 1993. 